\title{
Transient electromagnetic sounding in Sao Tome Cape - RJ - Brazil
}

\author{
Emanuele Laterra ${ }^{1}$ and Abel Carrasquilla ${ }^{2}$
} \begin{abstract}
Brennand Avenue S/N, Imboassica, Macae-RJ, 27930-480.
Copyright 2019, SBGf - Sociedade Brasileira de Geofísica

This paper was prepared for presentation during the $16^{\text {th }}$ International Congress of the Brazilian Geophysical Society held in Rio de Janeiro, Brazil, 19-22 August 2019.

Contents of this paper were reviewed by the Technical Committee of the $16^{\text {th }}$ International Congress of the Brazilian Geophysical Society and do not necessarily represent any position of the SBGf, its officers or members. Electronic reproduction or storage of any part of this paper for commercial purposes without the written consent of the Brazilian Geophysical Society is prohibited.
\end{abstract}

${ }^{1}$ Geophysics Coordination, National Observatory, General Jose Cristino Street, 77, Sao Cristovao, Rio de Janeiro, $20921-400$ ${ }^{2}$ Petroleum Engineering and Exploration Laboratory, Darcy Ribeiro Northern Rio de Janeiro State University, Km 163 Amaral Peixoto Highway,

described by Schaller (1973) and only considered in the stratigraphic chart of Winter et al. (2007).

\section{Method}

TDEM is a geophysical exploration technique which a current transient pulse induces electrical and magnetic in

\begin{abstract}
In 1959, Petrobras drilled the wellbore 2-CST-0001-RJ in Sao Tome Cape-RJ, the first one in Campos Basin. This well of $2600 \mathrm{~m}$ was discarded because there were not enough hydrocarbons to be produce. But, just before, lithological data and well logs were collected. Currently, we decided to carry out a survey close to this area using the transient electromagnetic geophysical method. The primary objective of the study was to verify the technique ability to solve quaternary and tertiary layers in this type of geological environment, and at the same time to compare the results with the data mentioned above. The results show the existence of a strong correlation between modeled and distinct layers of shale, sandstone and conglomerate. On the other hand, the anomalies of the spontaneous potential log have a clear coincidence with the interfaces of the geological layers.
\end{abstract}

\section{Introduction}

Transient electromagnetics (also time domain electromagnetics - TDEM) is a geophysical technique utilized in Sao Tome Cape, Rio de Janeiro (Figure 1), near to Petrobras 2-CST-0001-RJ abandoned well (Petrobras, 1959). The objective of the survey was to correlate the responses with the spontaneous potential (SP) log and lithological description of the well in its first hundred meters depth.

The geology in this area is formed by the Campos Group, which was deposited in the final phase of the thermal subsidence of the Campos Basin, and is composed of the Embore, Ubatuba, Carapebus and Barreiras Formations (Figure 2). Proximal sediments of the Embore Formation, forming by sand, conglomerate and carbonate, are found gradating to shale in the distal portion (Ubatuba Formation), with the presence of intercalated turbidite sandstone of Carapebus Formation (Milani et al., 2001). The Barreiras Formation only is found in the emergent portion of the Campos Basin, being marked by deposits of continental and fluvial origin (Figure 1). This formation was subsoil. Subsequently, a decay response of the secondary magnetic field is measured (Figure 3 ). The method is generally able to determine subsurface electrical properties but, it is also sensitive to subsurface magnetic properties (Fitterman \& Stewart, 1986). The surveys are a very common surface technique used throughout the world in both onshore and offshore applications. Its applications go through UXO (unexploded ordnance) detection and characterization, mineral search, groundwater exploration and, environmental mapping (Meju et al., 1993).

The configuration of the acquisition was a central loop mode and the survey point was in the Garoupa Farm, where the borehole is located. In this arrangement, the transmitter is a square loop - TX and, to measure the vertical magnetic field $-\mathrm{Hz}$, the receiver induction coil - $\mathrm{RX}$ is located at the center of the ring (Carrasquilla \& Ulugergerli, 2006). The characteristics of the research layout were: a) transmitter loop (TX) with a $100 \mathrm{~m}$ square loop, 10,000 $\mathrm{m}^{2}$ area, $2.5 \mathrm{~mm}^{2}$ wire and $7 \mathrm{Amp}$ current; b) receiver coil $(R X)$ with single channel induction coil of $10000 \mathrm{~m}^{2}$, being considered as a vertical dipole $\mathrm{Hz}$ (Figure 4).

To reduce the noise from the houses, the measurements were performed $200 \mathrm{~m} \mathrm{NW}$ from the wellhead position, being that, this displacement does not change the result of the comparison with lithological description, because it is a sedimentary basin where the layers are stratified and horizontal in that zone. In the acquisition, windows of the decay of the magnetic field $\mathrm{Hz}$ as a function of time with 53 samples were used, the triggering command was done manually, the intensity of the current was enough to induce magnetic fields up to $300 \mathrm{~m}$ depth and the composite mode was between $10^{-2}$ to $10^{2} \mathrm{msec}$ because the possible saturating fluids make the resistivity values low. The survey was planned to compare TDEM resistivity, SP log and lithological description in depth (Figure 5).

The licensed WinGlink (2018) program was used for editing and processing of field data, necessary to remove outliers in the measurements and remain only with the exponential decay points of the $\mathrm{Hz}$ field. The 1D Occam smoothed inversion (Constable et al., 1997) was performed using a parametrization of 20 -layers, with a stop criterion of 20 iterations and root mean square (rms) misfit 
of $1.5 \%$ of root mean square error ( $\mathrm{rms}$ ). The result was used as input in the inversion process, obtaining a model of 7-layers in real data fit. The error in the modeling was $1.5 \%$ rms with 99 iterations. A fine-tuning of $0.94 \mathrm{rms}$ was achieved after completing all the iterations.

\section{Results}

The lithological description of the well up to $270 \mathrm{~m}$ depth can be visualized in Figure 6 (Petrobras, 1959). The sedimentary rock is divided into shale and sandstone intercalations until this depth. The sandstone is from the surface till $25 \mathrm{~m}$ (yellow, Embore Formation, São Tomé Member, Quaternary), then comes the Barreiras Formation (Tertiary), where sandstone is yellow, shale is green, and conglomerate is brown. The sandstone formation is intercalated with shale as far as $1950 \mathrm{~m}$, where there is a basalt spillage of Lower Cretaceous Cabiunas Formation. The Precambrian gneissic basement occurs at $2600 \mathrm{~m}$, which is defined as economic basement (Gomes, 2013).

A layer of sandstone from surface to $30 \mathrm{~m}$ with resistivity of $250 \mathrm{ohm} . \mathrm{m}$ is shown in the $1 \mathrm{D}$ model and, associated to Embore Formation (Figure 7). From 30 to $100 \mathrm{~m}$ the resistivity falls to $70 \mathrm{ohm} . \mathrm{m}$, with the lithological description displaying intercalations of shale and sandstone associated to Barreiras Formation. At $100 \mathrm{~m}$ depth, a strong conductor of $1 \mathrm{ohm} . \mathrm{m}$ and $25 \mathrm{~m}$ thickness arise in the model, which was interpreted as a conglomerate associated with the Barreiras Formation maybe saturated by salty water. Above $100 \mathrm{~m}$ depth, there are many intercalations of shale and sandstone layers, resulting in resistivities close $70 \mathrm{ohm} . \mathrm{m}$ and $50 \mathrm{~m}$ thickness, together with another with 30 ohm.m and 400 m thickness. These responses may be caused by intercalations, which cause a different resistivity of the sandstone and the shale, with sandstone presenting resistivity values of two decades higher than the shale (Telford, 1990). A conductive layer is found at $1000 \mathrm{~m}$ with 2 ohm.m, perhaps composed of sandstone and shale intercalations and, impregnated with brine water. Over this depth, the method does not present a definition, so it is not possible to interpret.

Many agreements are observed between the low SP log anomalies and the shale layers along the well. Figure 6 exemplifies the previously declared, through coincidences among the red arrow connections with the different shale layers and the anomalies, for example, in 25, 50, $60 \mathrm{~m}$ depths, etc. Figure 8, on the other hand, shows the coincidences between the anomalies of the SP log, the different lithologies and the layers resulting from the 1D interpretation.

\section{Conclusions}

The result of the survey shows that the local stratification is well explained by coincidences between TDEM resistivity, lithological description and SP anomalies. The data inversion displays seven layers up to $1000 \mathrm{~m}$, in this order: 1) associated with sandstone; 2) sandstone, where the resistivity decreases with the shale intercalations; 3) strong conductive layer associated with conglomerate, probably containing brackish water; 4 and 5) two layers in succession, possibly being sandstone with numerous intercalations of shale layers; 6 ) another conductive layer, which can be interpreted as a sandstone having salty water; and, 7) above $1000 \mathrm{~m}$, where the method does not present resolution, so it is not possible to make an interpretation. This means that, in the tested geological environment, the TDEM method resolution can solve and to differentiate the geological strata.

\section{Acknowledgments}

We thank Petrogal Brasil S.A. by the support to develop this study, CNPq for the research grant, Phoenix Geophysics Ltd. for the help in the fieldwork and, UENFLENEP for the facilities.

\section{References}

- Carrasquilla, A. \& Ulugergerli, E. 2006. Evaluation of the transient electromagnetic geophysical method for stratigraphic mapping and hydrogeological delineation in Campos basin, Brazil. Brazilian Journal of Geophysics, 24(3): 333-341.

- Constable, S., Parker, R. and Constable, C. 1987. Occam's inversion: a practical algorithm for generating smooth models from EM sounding data. Geophysics, 52 : 289-300.

- Fitterman, D. \& Stewart, M. 1986. Transient electromagnetic sounding for groundwater. Geophysics, 51(4): 995-1005.

- Gomes, B. 2013. Lithological data (channel samples and interpretation of gamma ray log) of water wells in the Quissama region (RJ). Final Course Work, Institute of Geosciences, UFRJ, Rio de Janeiro, 37 p. (In Portuguese).

- Meju, M., Fontes, S. \& Oliveira, M. 1993. Joint TEM/AMT feasibility studies in Parnaıba Basin, Brazil: Geoelectrostratigraphy and groundwater resource evaluation in Piaui state. In: International Congress of the Brazilian Geophysical Society. Expanded Abstracts, Rio de Janeiro, SBGf, 2: 1373-8.

- Milani, E., Brandão, J., Zalán, P. \& Gamboa, A. Petroleum in the Brazilian continental margin: Geology, Exploration, Results and Perspectives.2000. Brazilian Journal of Geophysics, v. 18, n. 3, p. 351 - 396. (In Portuguese).

- Petrobras. 1959. Technical Report of Borehole 2-CST0001-RJ, Sao Tome Cape - RJ - Campos Basin. Rio de Janeiro.

- Schaller, H. 1973. Stratigraphy of the Campos Basin. Brazilian Congress of Geology, v. 27, p. 247 - 258. (In Portuguese).

- Telford, W. 1990. Applied Geophysics second Edition, Cambridge University Press, $2^{\text {nd }}$ edition, 750p.

- Villela, P. 2015. Faciological and stratigraphic aspects of the Emborê and Barreiras Formations in the well 2-JU-1RJ - Quissamã region (RJ), an emerging area of the Campos Basin. Masters Dissertation, UFRJ, Rio de Janeiro, 122 p. (In Portuguese).

- WinGlink. 2018. Geophysical Interpretation Software, User's Manual. Schlumberger Integrated Electromagnetic Center of Excellence, Milan - Italy.

- Winter, W., Jahnert, R. \& França, A. 2007. Campos Basin. Petrobras Geosciences Bulletin, v.15, n.2, p.511529. (In Portuguese). 

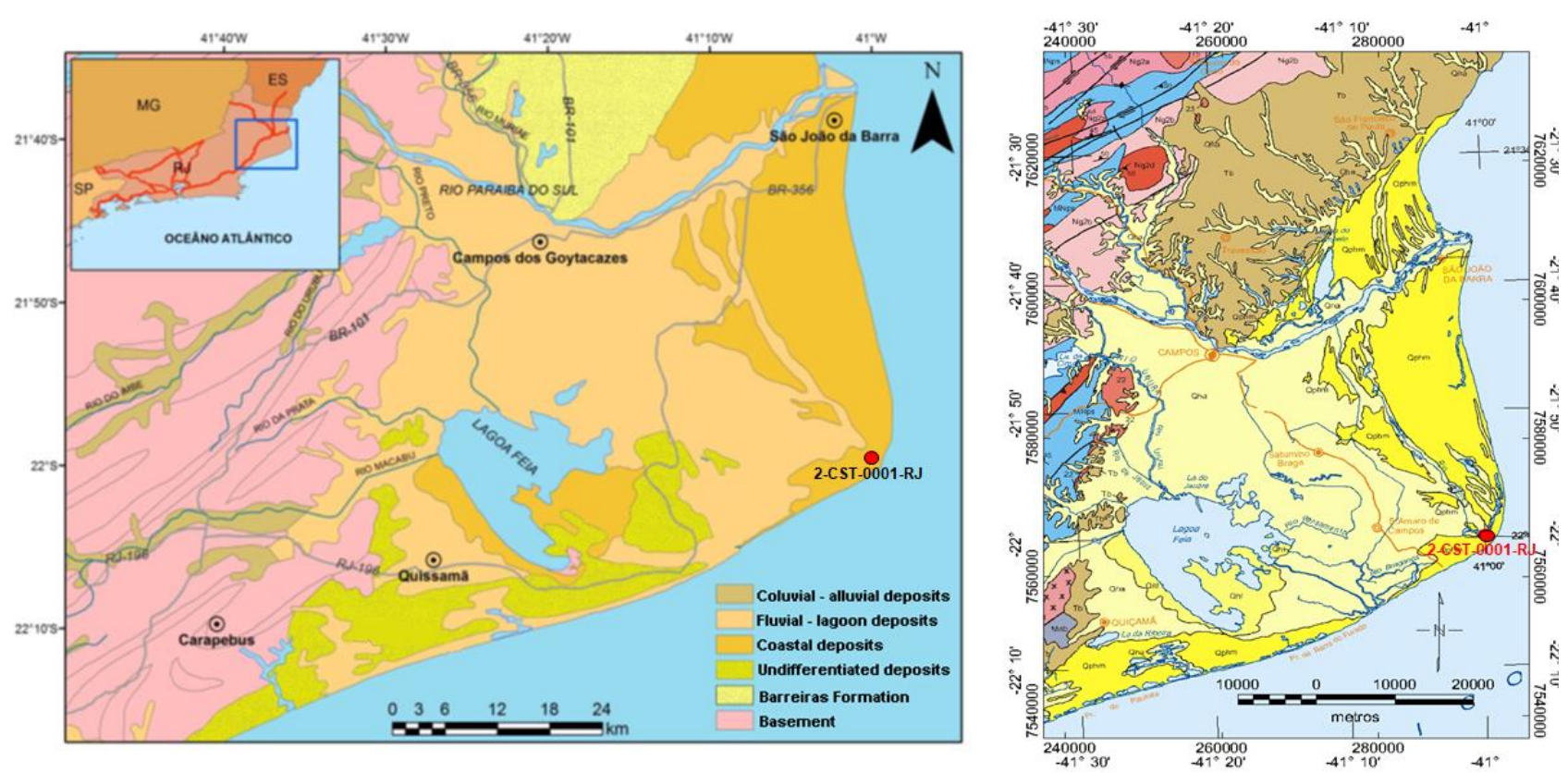

Figure 1. Geological map of the continental portion of Campos Basin. Left, the map with greater geological details. Right, the yellowish colors are geological formations of the quaternary (Embore, Ubatuba and Carapebus Formations), whereas the brown ones are of the Tertiary (Barreiras Formation). The red dot indicates the position of the well 2-CST-0001-RJ (modified from Villela, 2015).

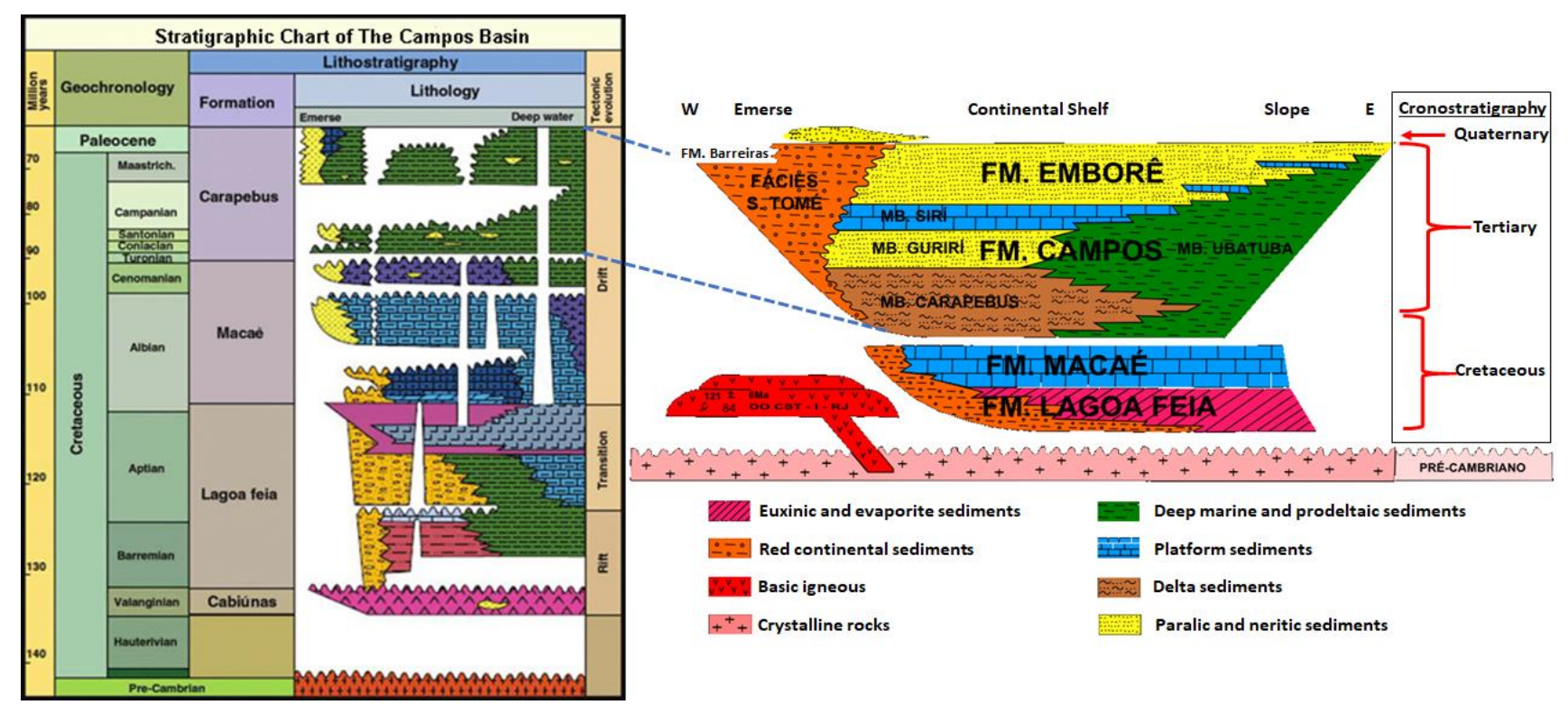

Figure 2. Lithostratigraphic column of the Campos Basin (modified from Schaller, 1973). 

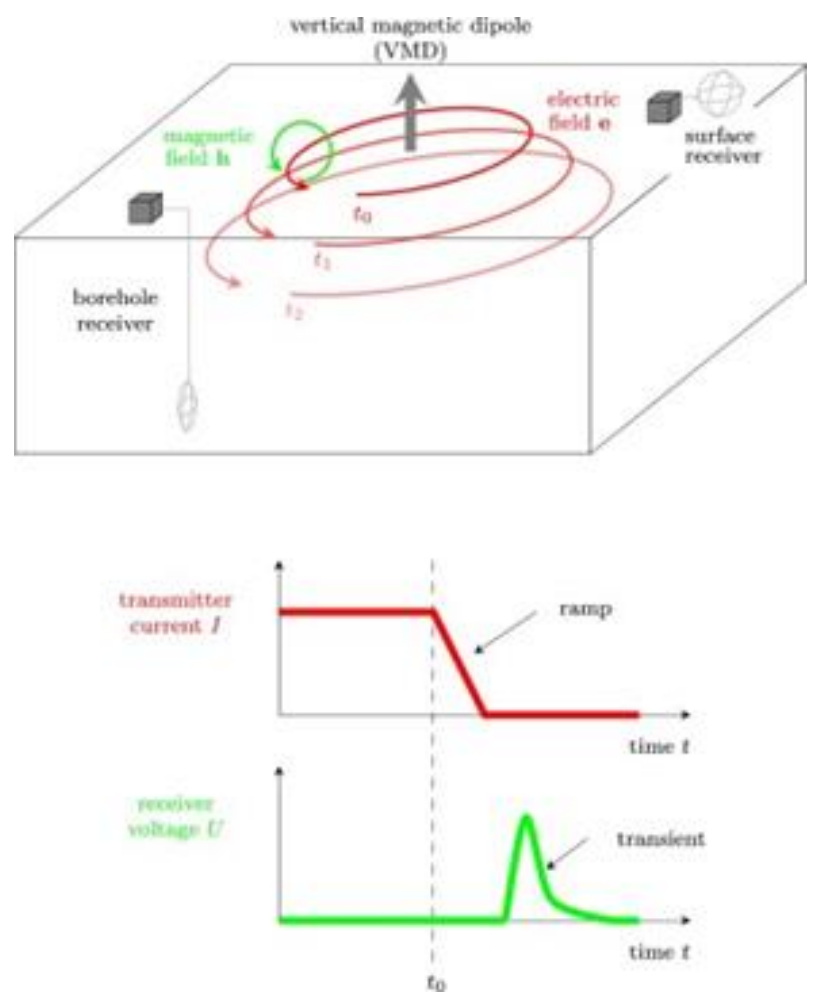

Figure 3. Above, subsurface induced currents that generate secondary fields measured as receptor. Below, transient in the transmitter current and measured voltage in the receiver (modified from Carrasquilla \& Ulugergerli, 2006).

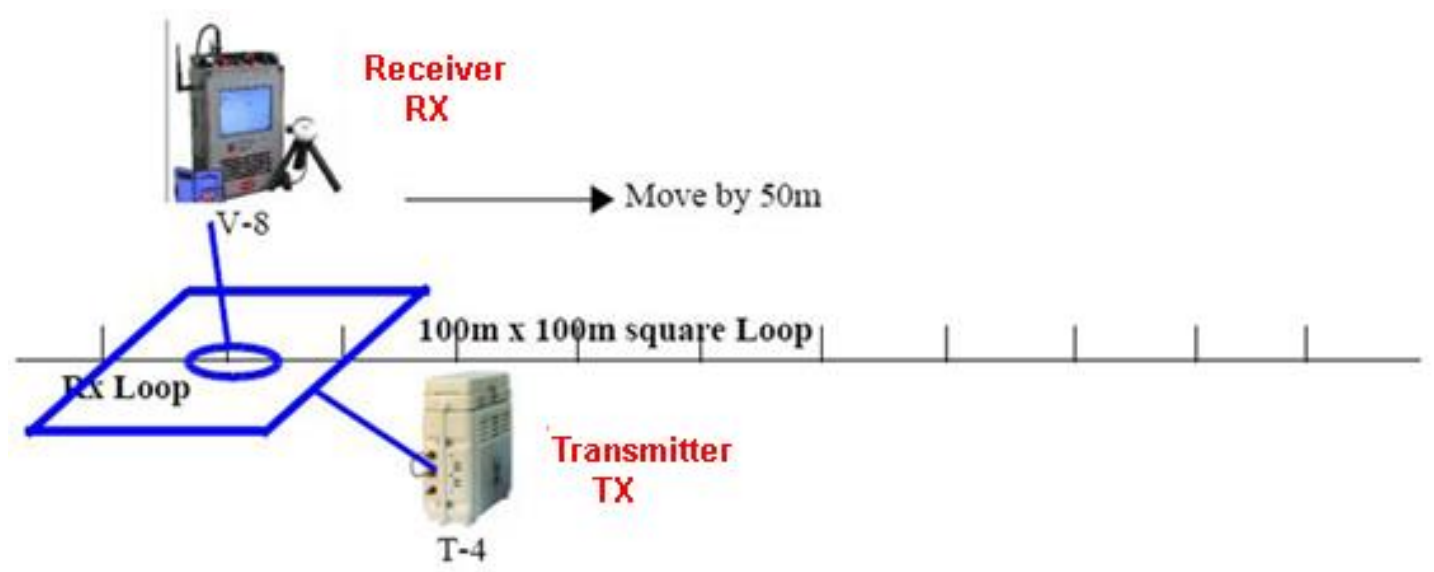

Figure 4. Central-Loop data acquisition configuration. 


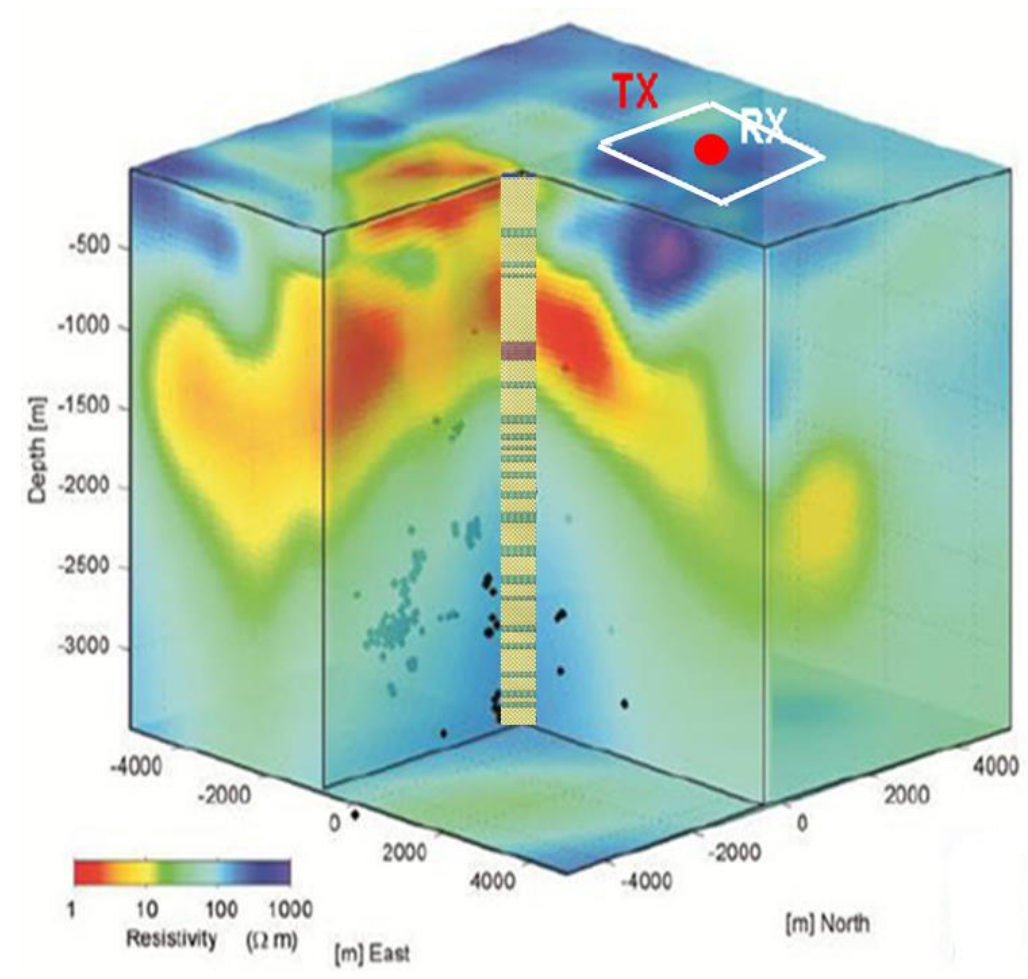

Figure 5. Data acquisition scheme with the TDEM method and compare with the lithological description, SP log anomalies and depth resistivity changes along the well.

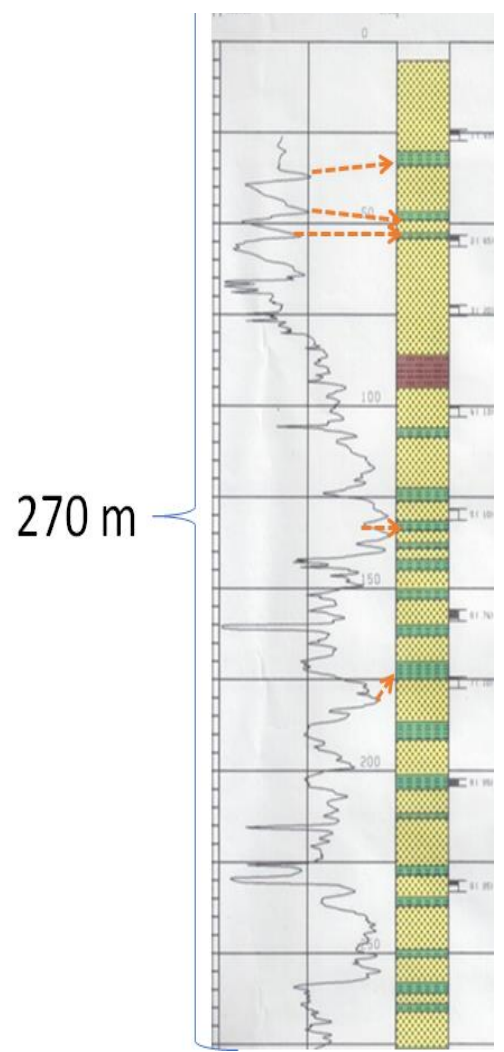

Figure 6. The coincidence of low values of the SP log with the shale layers are shown through some arrows. In the borehole, sandstone is yellow, shale is green, and conglomerate is brown (Petrobras, 1959). 


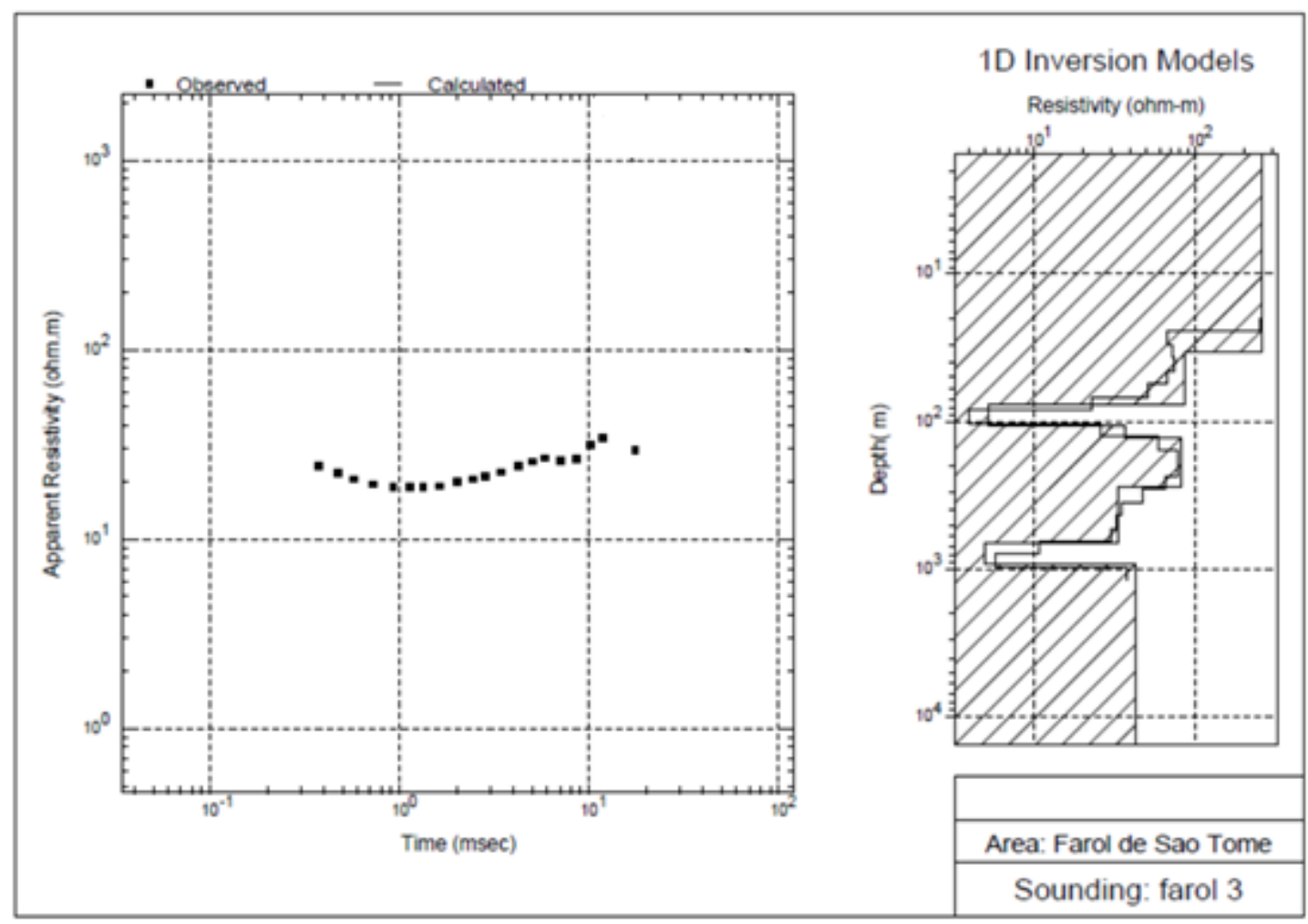

Figure 7. On the left panel the values of the resistivity measurements with TDEM and the right panel the 1D layer inversion model.

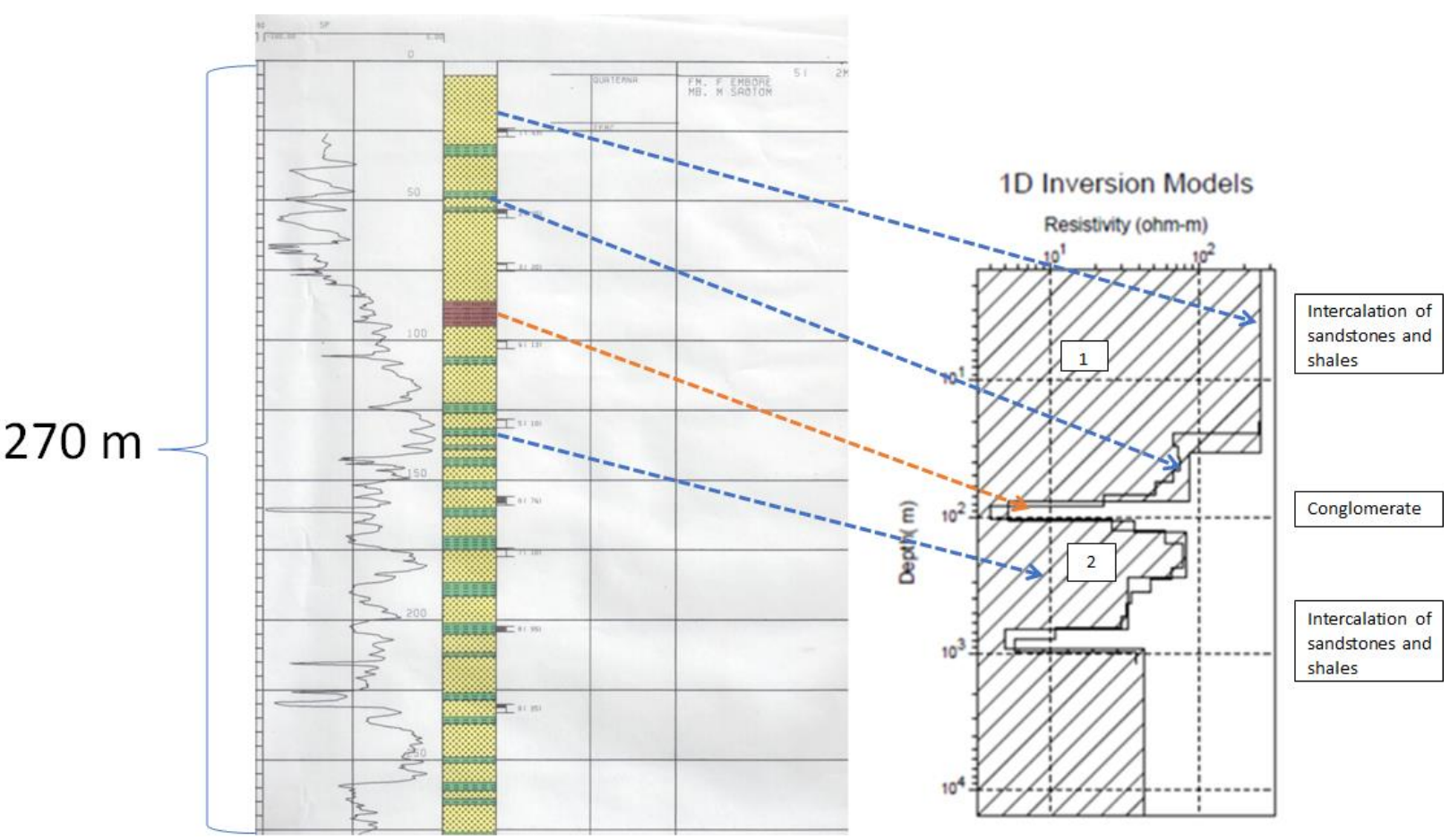

Figure 8. Comparison of the SP log and lithological profile of the 2-CST-0001-RJ well with the inverted 1D layer model. In evidence the low resistivity value of the Barreiras Formation conglomerate (in brown). 